Andrzej Prinke

(Polska Akademia Nauk Archiwum w Warszawie Oddział w Poznaniu)

\title{
Kierownik magazynu koszykarni: okupacyjny epizod z życia prof. Józefa Kostrzewskiego (1940-1943) w relacji prof. Alfreda hr. Wielopolskiego
}

Prof. Alfred hr. Wielopolski (ryc. 1.) ${ }^{1}$ skreślił poniższe wspomnienie na prośbę prof. Konrada Jażdżewskiego ${ }^{2}$, bliskiego przyjaciela i wieloletniego współpracownika prof. Józefa Kostrzewskiego - czołowego polskiego prehistoryka i współzałożyciela Uniwersytetu Poznańskiego. Wspomnienie dotyczy najdłuższego spośród wielu etapów okupacyjnej tułaczki Józefa Kostrzewskiego, zagrożonego aresztowaniem przez gestapo, po terenie Generalnego Gubernatorstwa (ryc. 2.). Jażdżewski wykorzystał następnie parę zawartych tam szczegółów w swym pamiętniku³. Autor niniejszych słów, w ramach kilkuletniej (2009-2016) kwerendy poświęconej życiu i dziełu Józefa Kostrzewskiego, podjął poszukiwania tego tekstu (m.in. w prywatnym archiwum Jażdżewskiego ${ }^{4}$ i w Archiwum Państwowym w Szczecinie, którego Wielopolski był pracownikiem), lecz przez dłuższy czas nie przynosiły one pozytywnego wyniku. Ostatecznie relację tę udało się odnaleźć w spu-

${ }^{1}$ Alfred hr. Wielopolski (ur. 9 października 1905 r. w Chrobrzu, pow. Pińczów, zm. 24 maja 1996 r. w Szczecinie) - ekonomista, politolog, historyk prawa i ekonomii; właściciel majątku Klemensówka k. Niska. Mgr prawa (Uniwersytet Warszawski 1927), dr nauk politycznych i ekonomii (Freiburg, Szwajcaria 1931) i prof. Uniwersytetu Technicznego w Szczecinie.

2 Konrad Jażdżewski (1908-1985) - prehistoryk, specjalista z zakresu archeologii neolitu Europy Środkowej i wczesnego średniowiecza Polski; uczeń, a następnie wieloletni bliski współpracownik i przyjaciel prof. Józefa Kostrzewskiego; w latach 1945-1971 prof. Uniwersytetu Łódzkiego (kierownik tamtejszego Zakładu Prehistorii, a następnie Katedry Archeologii); jednocześnie wieloletni dyrektor Muzeum Archeologicznego i Etnograficznego w Łodzi (początkowo: Miejskie Muzeum Prehistoryczne). Zob. A. Mikołajczyk, In memory of Prof. Konrad Jażdżewski (1908-1985), „Archeologia Polonia” 1991, nr 29, s. 161-170.

${ }^{3}$ K. Jażdżewski, Wspomnienia polskiego archeologa z XX wieku, Łódź 1995, s. 158-159.

${ }^{4}$ Obecnie w zbiorach Muzeum Archeologicznego i Etnograficznego w Łodzi. 


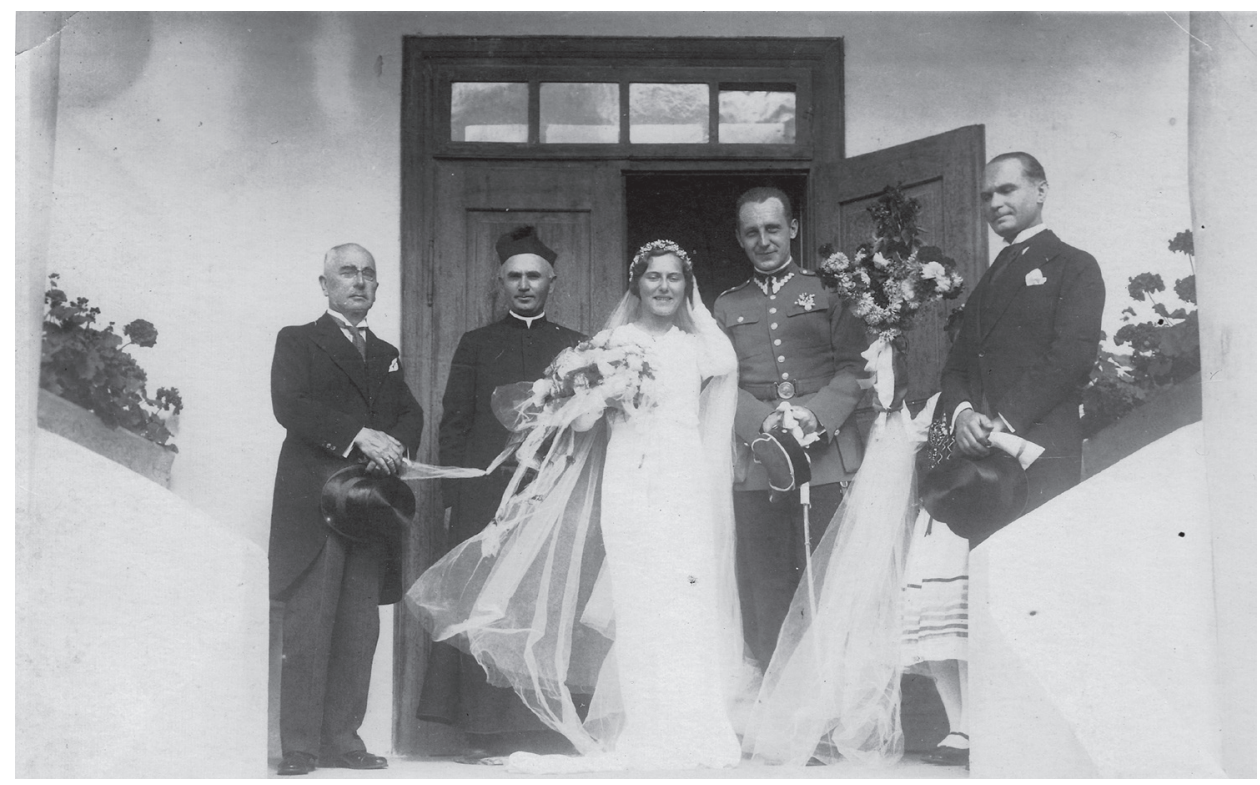

Ryc. 1. Prof. Alfred hr. Wielopolski (1905-1996) - ekonomista, politolog, historyk prawa i ekonomii; właściciel majątku Klemensówka k. Niska. Na zdjęciu: podczas ślubu z Salomeą Woytkowską, wnuczką mec. Stanisława Hofmokla (21 września 1935 r.).

ściźnie jej autora, znajdującej się w Bibliotece Zakładu im. Ossolińskich we Wrocławiu. Jest ona tam przechowywana jako materiał niezinwentaryzowany, gdyż została spisana na wtórnie wykorzystanych kartach o charakterze makulaturowym (sygn. Akc. 109/97), w dwóch wersjach: jako rękopis i maszynopis, nieco różniących się treścią. Poniżej przedstawiamy tekst tego wspomnienia $\mathrm{w}$ wersji maszynopisowej $\mathrm{z}$ zachowaniem pisowni oryginału.

\section{Alfred Wielopolski \\ WSPOMNIENIE O POBYCIE Ś.P. PROFESORA JÓZEFA KOSTRZEWSKIEGO PODCZAS WOJNY W KLEMENSÓWCE}

W 1940 a może 1941 (nie przypominam sobie dokładnie) zwrócił się do mnie śp. prof. Zygmunt Wojciechowski ${ }^{5} \mathrm{z}$ sugestią, abym udzielił schronienia prof.

${ }^{5}$ Zygmunt Wojciechowski (ur. 27 kwietnia 1900 r. w Stryju, zm. 14 października 1955 r. w Poznaniu) - historyk państwa i prawa, współtwórca koncepcji Polskiej Myśli Zachodniej; dr Uniwersytetu Jana Kazimierza we Lwowie (1924), od 1925 r. na Uniwersytecie Poznańskim: zastępca prof. (Katedra Historii Ustroju i Dawnego Prawa Polski), prof. zw. (1937). Pracownik Delegatury Rządu RP na Kraj (1940-1945); dyrektor Instytutu Zachodniego w Poznaniu (1944-1955); członek Polskiej Akademii Umiejętności (od 1945 r.) i Polskiej Akademii Nauk (od 1952 r.). 


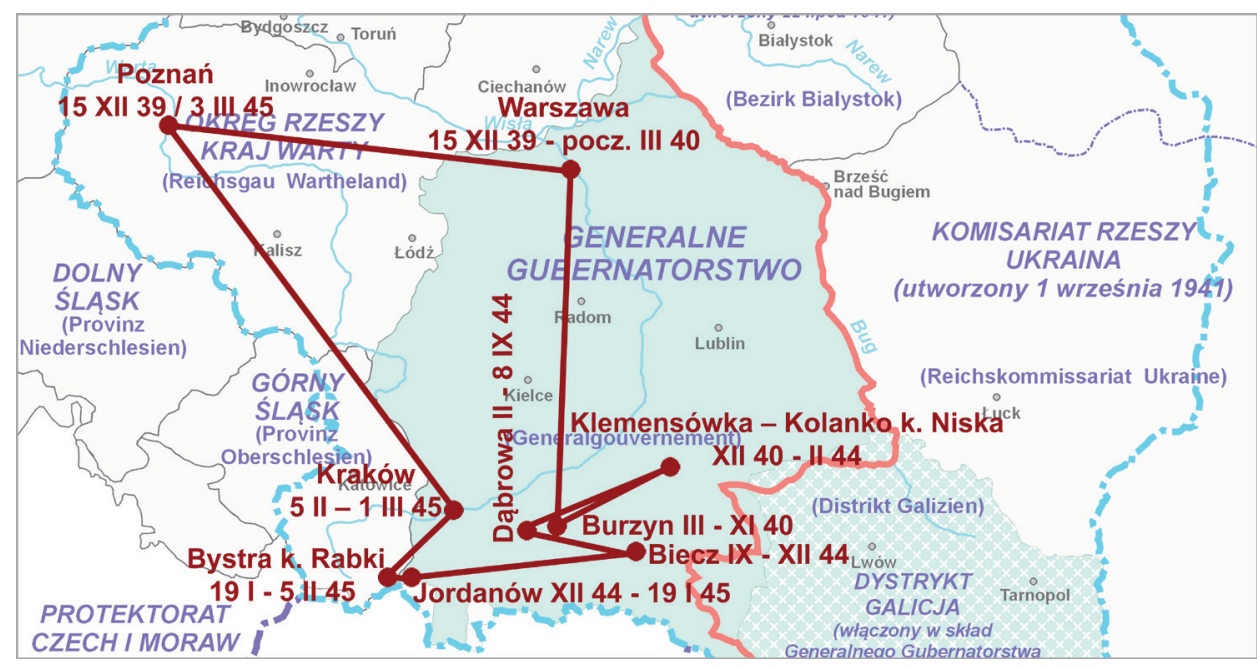

Ryc. 2. Mapa okupacyjnej tułaczki prof. Józefa Kostrzewskiego (15 grudnia 1939 r. - 3 marca 1945 r.). Wykonanie Andrzej Prinke.

Józefowi Kostrzewskiemu, będącego (sic!) w niebezpieczeństwie dostania się w ręce Gestapo [ryc. 3.]. Zamieszkiwałem wówczas w Zarzeczu k. Niska nad Sanem. Był to majątek będący własnością dr Stanisława Hofmokla, dziadka ${ }^{6}$ mojej żony. Dwór otoczony ogrodem był położony na wzgórzu tuż nad Sanem , a w odległości ok. 3 km znajdował się folwark Klemensówka. Właściciel majątku zamieszkiwał w tym dworze, a ja z żoną i dziećmi (sam byłem wtedy zdemobilizowanym ppor. rezerwy po odbyciu Kampanii wrześniowej, któremu udało się uniknąć [oflagu - skreśl.] dostania się do oflagu) zamieszkałem w Klemensówce, gdzie zajmowałem się gospodarstwem, na które składały się uprawa roli i produkcja koszykarska. Folwark składał się z piaszczystych pól dwóch części: piaszczystego pola i żyźniejszej części położonej nisko w dolinie Sanu, [Rzeka w tym miejscu tworzyła zakręt, tak że - skreśl.] oddzielonej od górnej partii granicznym laskiem sosnowym i stokiem opadającym ku dolinie. U stóp tego stoku znajdował się dość solidny drewniany budynek mieszkalny, [skład - skreśl.] szopa z urządzeniami do obróbki wikliny i niewielka obórka. [Z uwagi San na tworzył - skreśl.] Całość otaczającego

\footnotetext{
${ }^{6}$ Stanisław Hofmokl (ur. 1869 we Lwowie, zm. 1943 w Zarzeczu, pow. Nisko) - prawnik, ziemianin, mecenas sztuki, publicysta; adwokat we Lwowie, właściciel majątku Zarzecze k. Niska (od 1908 r.); teść prof. Alfreda Wielopolskiego z sąsiedniej Klemensówki. Podczas okupacji hitlerowskiej w jego majątku ukrywało się poza Kostrzewskim kilka innych wybitnych osób: Edward Bertold (prawnik, polityk, żołnierz Batalionów Chłopskich), Stefania Łobaczewska (muzykolog, prof. Uniwersytetu Jagiellońskiego i Państwowej Wyższej Szkoły Muzycznej w Krakowie) i Jerzy Sawicki (prawnik, adwokat we Lwowie, prof. Uniwersytetu Łódzkiego i Uniwersytetu Warszawskiego oraz felietonista, ps. Lex).
} 


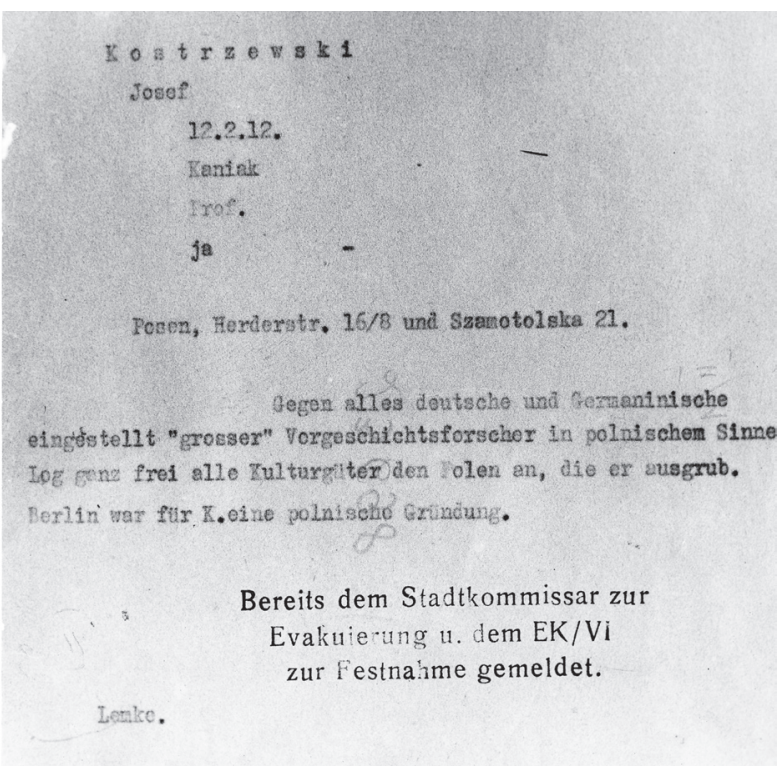

Ryc. 3. Nakaz aresztowania prof. Józefa Kostrzewskiego, wydany przez niemiecką administrację okupacyjną wkrótce po wybuchu wojny (jesień 1939 r.; Polska Akademia Nauk - Archiwum w Warszawie - Oddział w Poznaniu / PANAWOP, sygn. III P-51).

pola (plantacja wikliny) stanowiła jakby półwysep otoczony zakrętem rzeki; dzięki tej konfiguracji tę część obszaru folwarcznego nazywano: Kolanko. W niewielkim dworku, służącym za rządcówkę folwarku, w którym zamieszkiwałem z rodziną, było bardzo ciasno, a ponadto raz po raz zjawiali się tam nieproszeni goście z ramienia Kreislandrata7 ${ }^{7}$ : postanowiłem więc ulokować prof. Kostrzewskiego, ukrywającego się pod pseudonimem Edmunda Bogdajewicza ${ }^{8}$ w owym drewnianym domu na Kolanku. Dom ten zajmował z rodziną p. Karol Bilicz, moja prawa ręka w zarządzaniu produkcją koszykarską. Profesor Kostrzewski zamieszkał tam w skromnym pokoju pod bezpośrednią opieką tej szlachetnej rodziny, złożonej z rodziców i dwóch córek. Zarówno z uwagi na osobę p. Karola Bilicza, zasługującego na pełne zaufanie, troskliwość jego małżonki i położenie najzupełniej na uboczu, schronienie to zapewniało w danych warunkach najlepsze warunki bezpieczeństwa. Z drugiej jednak strony profesor był skazany na smutne przebywanie w warunkach dość prymitywnych na całkowitym niemal odludziu. Jedyną materialną atrakcją którą można mu było świadczyć było zapewnienie wystarczającej ilości nafty do lampy na długie jesienno-zimowe wieczory, podczas których pisał swoje prace naukowe.

${ }^{7}$ Kreislandrat - w systemie niemieckiej administracji okupacyjnej w Generalnym Gubernatorstwie: naczelnik okręgu (odpowiednik starosty).

${ }^{8}$ Edmund Bogdajewicz (ur. 1895 w Grabowie nad Prosną, zm. 1969 w Poznaniu) - malarz pokojowy. W grudniu 1939 r. podziemna polska komórka legalizacyjna przerobiła jego przedwojenny dowód osobisty na dokument tożsamości Józefa Kostrzewskiego. 
Jakby na ironię losu na stoku wzdłuż drogi prowadzącej do Kolanka znajdowało się cmentarzysko kultury prasłowiańskiej ${ }^{9}$. Przed wojną podczas uprawiania tego pola wykopywano urny ${ }^{10}$, których kilka egzemplarzy zabezpieczono $\mathrm{w} b$. dobrym stanie. Jedna $\mathrm{z}$ nich umieszczona na postumencie zdobiła jeden z pokoi w dworze w Zarzeczu. Opowiadano mi, że w 1945 r. pocisk artyleryjski trafił w ścianę obracając pokój w stan opłakany, ale urna na swym postumencie trwała nietknięta; nie wiem niestety co się z nią następnie stało. Przechadzając się wzdłuż tego pola, profesora brała zapewne nieraz chętka podjęcia archeologicznych poszukiwań, co jednak mogłoby spowodować niepożądane zainteresowania pod adresem jego osoby.

Urozmaiceniem monotonnej egzystencji były od czasu do czasu odwiedziny Pani Kostrzewskiej ${ }^{11}$. Któregoś lata odwiedził go także Gerard Labuda ${ }^{12}$, aby zaliczyć przedmiot do przeprowadzanego w ramach tajnego nauczania przewodu doktorskiego.

Pomimo zamieszkiwania oddzielnie, spotykałem się jednak z miłym podopiecznym niemal codziennie. Nasze rozmowy dotyczyły głównie aktualnych wydarzeń wojenno-politycznych. Niejednokrotnie nawiązywały też do naukowych zainteresowań profesora: przypominam sobie jego zapał polemiczny w stosunku do niektórych (ale nie pamiętam już jakich) tez Brücknera ${ }^{13}$ : utkwiło mi to $\mathrm{w}$ pamięci, ponieważ $\mathrm{w}$ takich chwilach profesor wymamrotał nazwisko oponenta: „Brücknerek twierdzi to czy tamto”. Tak to gawędziliśmy. Profesor niejednokrotnie zwracał się do mnie abym mu zlecił jakieś prace $\mathrm{w}$ folwarku. Nieraz przesiadywaliśmy na workach z ziarnem, gdy nadzorowałem młockę przy młocarni. Profesor był niezwykle subtelny i delikatny i nigdy nie usłyszałem z jego ust utyskiwań lub żalu na jego godną politowania sytuację. Nie usłyszałem także nigdy słowa na jego aktualne warunki egzystencji, które niestety były aż za bardzo spartańskie. Zamiast tego starał się być jak najbardziej uczynnym dla otoczenia. Młodszej córce państwa Biliczów

\footnotetext{
9 Ścisłej: kultury łużyckiej.

${ }^{10}$ Prawidłowo: popielnice.

11 Jadwiga Kostrzewska z d. Wróblewska (ur. 1886 w Poznaniu, zm. 1954 tamże) - żona prof. Kostrzewskiego, z zawodu guwernantka.

12 Gerard Labuda (ur. 1916 w Nowej Hucie k. Kartuz, zm. 2010 w Poznaniu) - historyk mediewista, prof. (1950) i rektor (1962-1965) UAM w Poznaniu, wiceprezes PAN (1984-1989), prezes PAU (1989-1994).

${ }^{13}$ Aleksander Brückner (ur. 1856 w Brzeżanach, zm. 24 maja 1939 r. w Berlinie) - polski prof., filolog i slawista, historyk literatury i kultury polskiej. Studia we Lwowie, staże naukowe w Lipsku, Berlinie i Wiedniu; habilitacja: Wiedeń 1878; doc. Uniwersytetu Lwowskiego, od 1881 r. prof. w Berlinie. Członek Polskiej Akademii Umiejętności w Krakowie, Rosyjskiej Akademii Nauk w Petersburgu i Towarzystwa Naukowego we Lwowie, dr h.c. Uniwersytetu Warszawskiego (1929), odznaczony Złotym Wawrzynem Akademickim Polskiej Akademii Literatury (1935), Krzyżem Komandorskim z Gwiazdą Orderu Odrodzenia Polski (1929). Zob. W. Berbelicki, Aleksander Brückner. 1856-1939, Warszawa 1989.
} 
Bogusi $^{14}$ udzielał lekcji języka niemieckiego, a zdaje się i innych przedmiotów. Często zwracał się do mnie, aby mu powierzyć jakieś konkretne prace gospodarskie. Byłem pod tym względem w kłopocie, nie chcąc go narażać na wysiłki, do których przecież nie był przyzwyczajony. Pod wpływem nalegań zaproponowałem mu któregoś przedwiośnia prześwietlanie koron drzew w sadzie wiśni przylegającym do folwarku. Profesor z niebywałą systematycznością wykonywał to zadanie $\mathrm{w}$ chłodnych nieraz podmuchach marcowych.

Jak to bywa w codziennym wzajemnym kontakcie, czasem się z profesorem żartobliwie droczyłem na dwa tematy, w których był nieustępliwy: jego pryncypialnej abstynencji antyalkoholowej i jego werbalnego antysemityzmu. Ale co się tyczy tego drugiego, to zdarzyło się, że pojawił się jakiś Żyd z dalszych stron, dla którego trzeba było znaleźć schronienie na kilka dni. Przypominam sobie, jak słysząc o tym, profesor zerwał się energicznie z worka z ziarnem, na którym właśnie siedział i podążył do okolicznych gospodarzy w poszukiwaniu schronienia dla przybysza.

Któregoś dnia latem woda w Sanie zaczęła gwałtownie przybierać: rzeka wystąpiła z brzegów i zalała część obszaru Kolanka zbliżając się do zabudowań. Kiedy zaniepokojony przybyłem na miejsce zastałem profesora, jak [na] podwórzu klecił drewnianą tratwę. Była to tratwa iście profesorska nie wiem czy wytrzymałaby pod ciężarem małego dziecka. Ale profesor którego posądzałem, że kleci okolicznościową zabawkę ustosunkował się do swego dzieła z całą powagą i przekonaniem o jego efektywności. Był to widocznie taki twórczy odruch warunkowy w obliczu zagrożenia, które zresztą szczęśliwie ustąpiło bez potrzeby wypróbowania w praktyce przyrządu ratowniczego.

Pod koniec pobytu profesora na Kolanku, w 1943 czy 1944 r., stosunki w okolicy stawały się coraz trudniejsze. Zaczęły się obławy niemieckie na partyzantów, kończące się wywózką ludzi na roboty do Niemiec, a także warunki bezpieczeństwa były coraz gorsze. Państwo Biliczowie przeżyli ciężką tragedię rodzinną: ich starsza córka wnet po wyjściu za mąż za leśniczego w lasach na Zamojszczyźnie została wraz z mężem zamordowana przez hitlerowców podczas przeprowadzanej tam akcji pacyfikacyjnej. Warunki bezpieczeństwa pogarszały się także ze względu na nocne napady z lasu, sam niejednokrotnie padłem ofiarą takich wizyt, które ogałacały nie tylko folwark z inwentarza, ale także z zasobów osobistej garderoby. Pewnego razu miał też miejsce napad na dom na Kolanku, podczas którego pobito dotkliwie p. Karola Bilicza, zabierając mu jego osobiste rzeczy i obrabowując dom

${ }^{14}$ Bogusława Bilicz-Wierzbowska; po wojnie osiadła w Warszawie, gdzie ukończyła studia i założyła rodzinę; przez wiele następnych lat utrzymywała serdeczny kontakt korespondencyjny (w spuściźnie Profesora zachowało się 68 jej listów). 
z odzieży ${ }^{15}$. Sam siedmiokrotnie padłem ofiarą takich wizyt rzekomo patriotycznych a $w$ istocie rabunkowych które ogałacały nie tylko folwark $\mathrm{z}$ inwentarza, ale [i] z zasobów osobistej garderoby. To, a także możliwość uzyskania innego schronienia, skłoniło profesora do opuszczenia meliny na Kolanku. Pozostawił po sobie pamięć człowieka o nieprzeciętnej skromności i subtelności uczuć. Kilka lat potem moje dzieci, kiedy już podrosły, pytały mnie, kim był ten tajemniczy pan. Próbowałem im wyjaśnić jego dokonania naukowe a na tym tle powstała dla nich opowiastka, którą pozwalam sobie do tej krótkiej relacji dołączyć ${ }^{16}$.

Migawka wspomnieniowa spisana z fragmentu rękopisu, który znajduje się na odwrocie pozycji 24: Opowiadanie Janiny, w teczce p.t. Fragmentaryczne notatki...; przepisał Aleksander Labuda.

\section{Podziękowania}

Sukces opisanych powyżej poszukiwań nie byłby możliwy bez życzliwości i pomocy szeregu osób, którym autor winien jest w tym miejscu podziękowanie. Są to: prof. dr hab. Aleksander Labuda, Wrocław (za cenne konsultacje), pracownicy Biblioteki im. Ossolińskich we Wrocławiu - Dział Zbiorów Specjalnych (za skuteczną pomoc w dotarciu do poszukiwanego dokumentu), pracownicy Archiwum Państwowego w Szczecinie: wicedyrektor mgr Maria Frankel i dr hab. Maciej Szukała (za wydatną pomoc w poszukiwaniach), mgr Maria Jażdżewska-Majda, Łódź (za udostępnienie archiwum Jej Ojca - prof. Konrada Jażdżewskiego), pani Aniela Ryznar z Zarzecza k. Niska (mój przewodnik po okolicach Klemensówki i Zarzecza) oraz dr Olga Czekała (za wszechstronne wsparcie).

\section{Bibliografia}

Berbelicki W., Aleksander Brückner. 1856-1939, Warszawa 1989.

Jażdżewski K., Pamiętniki. Wspomnienia polskiego archeologa z XX wieku, Łódź 1995.

Kaczmarek J.E., Prinke A., Żywot długi, pracowity i spetniony. Profesor Józef Kostrzewski (1885-1969) - prehistoryk, patriota, Europejczyk, Poznań [w druku].

Kostrzewski J., Z mego życia. Pamiętnik, Wrocław 1970.

Mikołajczyk A., In memory of Prof. Konrad Jażdżewski (1908-1985), „Archaeologia Polona” 1991, nr 29, s. 161-170.

Ogiński J., Dziedzic z Zarzecza k. Niska, „Sztafeta” nr 13: 13, z 29 marca 2001 r.

15 Poszkodowany został wówczas również prof. Kostrzewski. przebieg napadu opisał w swym pamiętniku: J. Kostrzewski, Z mego życia. Pamiętnik, Wrocław 1970, s. 236-241.

16 Tekst pt. O pra-pra-pra-dziaduniu i pra-pra-pra-babuni, którzy żyli w Biskupinie, napisany w konwencji Starej baśni Józefa Ignacego Kraszewskiego (mps o objętości sześciu stron). 
Andrzej Prinke

\title{
Kierownik magazynu koszykarni: okupacyjny epizod z życia prof. Józefa Kostrzewskiego (1940-1943) w relacji prof. Alfreda hr. Wielopolskiego
}

\begin{abstract}
Streszczenie
W tekście przedstawiono wspomnienie dotyczące fragmentu okupacyjnego okresu życia czołowego polskiego prehistoryka i współzałożyciela Uniwersytetu Poznańskiego - prof. Józefa Kostrzewskiego. Autorem przytoczonej pracy jest prof. Alfred hr. Wielopolski, politolog i ekonomista, a także historyk ekonomii i prawa. Odnaleziony w Bibliotece Zakładu im. Ossolińskich we Wrocławiu maszynopis, relacjonuje życie prof. w okresie od grudnia 1940 do lutego 1944 roku, kiedy prof. Kostrzewski ukrywał się w majątku Klemensówka k. Niska.
\end{abstract}

\section{Manager of the basket workshop warehouse: the period of occupation in the life of professor Józef Kostrzewski (1940-1943) in the account of professor count Alfred Wielkopolski}

\begin{abstract}
The text presents the recollection of the occupational period in the life of a leading Polish prehistorian and a co-founder of the Poznań University, professor Józef Kostrzewski. The author of the work quoted is professor count Alfred Wielkopolski, a political scientist, economist and economic and law historian. The manuscript found in the library of the National Ossoliński Institute in Wrocław provides the account of Kostrzewski's life in the period between December 1940 and February 1944, when he remained in hiding in the Klemensówka estate, near Nisko.
\end{abstract}

